\title{
OLEKSII SHESTAKOVSKYI,
}

Candidate of Sciences in Sociology, independent scholar, Kyiv

\section{MAXIM KASIANCZUK,}

Candidate of Sciences in Chemistry, Monitoring and Evaluation Coordinator at the Eurasian Coalition on Male Health, Tallinn, Estonia

\section{OLESIA TROFYMENKO,}

Leading sociologist at the Department of Social Expertise, Institute of Sociology, National Academy of Sciences of Ukraine, Kyiv

\section{GULBARSHYN CHEPURKO,}

Doctor of Sciences in Sociology, Head of the Department of Social Expertise, Institute of Sociology, National Academy of Sciences of Ukraine, Kyiv

\section{VITALY DJUMA,}

Master of International Public Health, Executive Director of the Eurasian Coalition on Male Health, Tallinn, Estonia

\section{SEAN HOWELL,}

co-founder and President of Hornet Networks Ltd., USA

\section{Internal homonegativity among men having sex with men: a comparative cross-national study}




\section{Introduction}

Internalized homonegativity $(\mathrm{IH})$ is an important factor related to poorer health of MSM, their inadequate access to relevant health services and worse community life inclusion. IH can be defined as a negative attitude towards one's own homosexuality, adopted by MSM in homophobic societies ${ }^{1}$ [Berg, MuntheKaas, \& Ross, 2016; M.W.Ross \& Rosser, 1996; Mayfield, 2001]. It occurs when gays, bisexuals or other MSM uncritically assimilate predominant negative attitudes and assumptions about homosexuals and homosexuality during socialization, and feel shame, contempt, and other negative feelings about themselves [Malyon, 1982; Shidlo, 1994; Szymanski, Kashubeck-West, \& Meyer, 2008a]. In other words, IH represents a stigma towards homosexuality that exists in society. MSM accept this stigma, stigmatizing themselves [Herek, 2004; Herek, Gillis, \& Cogan, 2009].

The relation between IH and the level of homosexuality stigma in society is known. Thus, an average IH is associated to the extent to which local legislation protects or discriminates them [B.R.S.Rosser et al., 2011, Berg, Ross, Weatherburn, \& Schmidt, 2013]. IH is higher among respondents in countries where the rejection of homosexuality is common among public opinion, where LGB people perceive the social environment as unfriendly [Berg, Lemke, \& Ross, 2017], and where access to public health services is more limited [Berg et al., 2013].

In terms of word usage, the word homophobia was used in the past for the concept describing homosexuals' "self-loathing" [Weinberg, 1972]. However, the current consensus is that hostility and negative attitudes towards homosexuals are manifestations of massively widespread cultural stigma and not an individual psychological pathology [Herek, 2004; Shidlo, 1994]. In the case of selfhomophobia, internalized homonegativity, internalized heterosexism, or selfstigma were suggested [Herek, Gillis, \& Cogan, 2009]. More than 30 scales with a different conceptual design were developed in order to measure IH, since it is a multidimensional phenomenon [Bell \& Weinberg, 1978; Lingiardi, Baiocco, \& Nardelli, 2012; Mayfield, 2001; Nungesser, 1983; M.W.Ross \& Rosser, 1996; Shidlo, 1994; Szymansky, Kashubeck-West, \& Meyer, 2008].

The structure of IH research is expanding, primarily to the consequences of IH for gays' and other MSM' health. IH is associated with poorer psychological health of MSM: lower self-esteem, depressive symptoms, loneliness and more frequent suicidal thoughts [Berghe, Dewaele, Cox, \& Vincke, 2010; Lingiardi et al., 2012; Newcomb \& Mustanski, 2011; Nungesser, 1983; M.W.Ross, Simon Rosser, \& Neumaier, 2008; Rosser, Bockting, Ross, Miner, \& Coleman, 2008; Shidlo, 1994; Williamson, 2000].

There is evidence of relation, direct and indirect, between IH and risky sexual behavior, such as unprotected anal sex, the number of random partners, compulsive sexual behavior, difficulty of deterring the desire to have sex, as well as the experience of commercial sex [Morell-Mengual, Gil-Llario, Ballester-Arnal, \& Salmeryn-Sanchéz 2017; M.W.Ross, Kayub, Mandel, McFarland, \& Ray-

1 Similar internalized homonegativity also exists among lesbians and bisexual women (Shidlo, 1994; Williamson, 2000), but it is not the subject of this article. 
mond, 2013; M.W.Ross et al., 2013; Smolensky, Ross, \& Rosser, 2011; Xu, Zheng, $\mathrm{Xu}$ \& Zheng 2017].

In general, IH should be considered as one of the factors reducing both the effective prophylaxis and the treatment of HIV among MSM. Since self-incrimination can reduce the desire for MSM to undergo testing, IH is associated with the likelihood of passing an HIV test [Pyun et al., 2014; M.W.Ross et al., 2013; see also Shoptaw et al., 2009], as well as other STI [Berg, Ross, Weatherburn, \& Schmidt, 2013], and may be a significant predictor of undiagnosed HIV infection [Young, Shoptaw, Weiss, Munjas, \& Gorbach, 2011]. Higher homonegativity is associated with lower awareness of available services and lower willingness to participate in preventive interventions with other MSM [Huebner, Davis, Nemeroff, \& Aiken, 2002], lower awareness of HIV and MSM, and worse access to free condoms [Berg et al., 2013], and in general, the effectiveness of preventive measures [Santos et al., 2013].

Different studies among HIV-positive gays have shown that IH are associated with a higher probability of unprotected receptive anal contacts, depressive and anxious symptoms, more often use of drug-stimulants, and less favored antiretroviral therapy [Johnson, Carrico, Chesney, \& Morin, 2008; M.W.Ross et al., 2008].

It is also significant that MSM with higher IH are less related to gay and LGBT community [Herek, Cogan, Gillis, \& Glunt, 1998; Lingiardi et al., 2012; Meyer \& Dean, 1998; Smolenski et al. 2010]. In terms of prevention, this means that homosexual MSM may be less inclined to attend gay and bisexual organizations and participate in their work.

This far from being exhaustible list of works is exclusively based on studies conducted in Western Europe or the United States. We know only few IH studies, conducted in Eastern Europe and Central Asia (EECA), mainly in Ukraine, the Russian Federation and Estonia. At present, we are not aware of this phenomenon in other Baltic countries, nor in Central Asia and South Caucasus.

A number of the above mentioned works were written using European MSM Internet Survey (EMIS) data. It included data about MSM in Belarus, Moldova, Russia, Ukraine, and Estonia [Berg et al., 2017, 2016, 2013, 2015; M.W.Ross et al., 2013], but aggregated only within the larger macroregions of Europe. Separate descriptive reports were written for Estonia [Lõhmus, Murd, \& Trummal, 2012] and Russia [Shmykova, 2011], but only the latter managed to find an average IH level.

A separate study on the association of IH with different MSM health indicators was performed in Estonia (Parker, Lõhmus, Mangine, \& Rüütel, 2016), but the results failed to find any tangible relation.

In Ukraine, the relation between internalized homonegativity and indicators related to sexual health, HIV and STI prevention were examined in two studies at least: a national integrated bio-behavioral study, and a survey of bisexuals [Kasyanchuk, Trofimenko, Bilous, \& Sazonova, 2017; Kasyanchuk, 2014]. In the study of bisexuals, homonegativity was associated with alcohol consumption and greater fears about coming out [Kasyanchuk, 2014]. On the other hand, higher homonegativity was associated a greater number of male partners in the last 6 months, which contradicts with some of the results mentioned above [Smolenski et al., 2011]. The level of IH was also evaluated in a study on possible strategies 
for implementing so-called pre-contact HIV prophylaxis (PHIVP) [Dubov, Fraenkel, Yorick, Ogunbajo, \& Altice, 2017].

Also, in Russia and Ukraine, separate studies were carried out, which raise the question of the correlation between IH and socialization [Kharchenko, 2014; Lapshina \& Kochetkova, 2016], the phenomenon of IH itself is studied [Sabunaeva, 2011]. IH scales are adapted or constructed [Yanykin \& Nasledov, 2017; Kasyanchuk, 2014].

Unsolved parts of the problem. Most of the available IH data relate to the United States and Western Europe. Although post-socialist countries of the EECA region may have their own specific features, there is some contradiction between the lack of IH study in the region and the expected prevalence of homonegativity (homophobia) in these societies.

In a rating of rights equality for gays, lesbians, bisexual, transgender and intersex people (LGBTI) in 49 European countries, the majority of Eastern European countries occupy lower rankings ${ }^{1}$. Legal climate and public opinion towards homo- and bisexuality tend to be worse in post-soviet countries than in Western Europe [Michael W. Ross et al., 2013]. The attitudes towards LGBTI employees in the key social services provided in the region of Central and Eastern Europe and Central Asia (CEECA) are predominantly negative [Moskotina, Dmitruk, Trofimenko, Privalov, \& Kasianczuk, 2017]. Therefore, it can be expected that the internalized homonegativity among MSM will be higher in these countries both by nature and as a factor in reducing the effectiveness of relevant public health programs.

Most of these works were carried out in connection with HIV prevention issues. At the same time, the vast majority of publications in the former Soviet Union belong to the so-called "Gray literature"; they are not peer-reviewed publications, and their results are not included in academic circulation. Except for bio-behavioral research data in Ukraine, performed on very large samples, other studies (especially in Russia and Estonia) cover small numbers of respondents, sometimes they are of a purely qualitative nature.

The very existence of a validated method for measuring IH remains problematic. Each of these surveys used its own instrument for measuring IH level (in general, there are more than 30 of them in the world [Mayfield, 2001]), so the results cannot be compared within one country.

Thus, given the significant role of IH as a factor of well-being (both mental and physical) of 1-3\% (according to various estimates) of adult men, as well as the fact that in the HIV service for MSM the processes of international standardization of the minimum package of services are ongoing, an important issue for the organizations of the state and non-state sectors of the region is to obtain comparable data.

Within the aim of systematically examining IH, its factors and the health of MSM, the Eurasian Coalition for Male Health (ECOM) initiated an online MSM survey in the region, which was the first study of this scale. Basing on the

1 See https://rainbow-europe.org/country-ranking 
data of this survey, we outline the results of the validation of the IH scale, its application in different countries, and its relation with socio-demographic factors ${ }^{1}$.

\section{Short IH scale (SIHS)}

There are more than $30 \mathrm{IH}$ measurement scales in the world [Mayfield, 2001]. We are using the so called Short IH scale or SIHS (Short Internalized Homonegativity Scale, SIHS) [Currie, Cunningham, \& Findlay, 2004; M.W.Ross et al., 2010; M.W.Ross \& Rosser, 1996; Smolenski, Diamond, Ross, \& Simon Rosser, 2010]. SIHS consists of seven or eight statements (see below). It is an improved version of the so-called Short Internalized Homonegativity Scale, SIHS (Michael W. Ross \& Rosser, 1996) (Currie, Cunningham, \& Findlay, 2004; Smolenski et al., 2010).

The scale was used in a massive MSM Internet survey which covered 174209 participants from 38 countries in 2010 [Michael W. Ross et al., 2013; The EMIS Network, 2013; Weatherburn et al., 2013], and was included in the similar global survey in 2017. The advantages of the given scale were not limited to its popularity, compactness and recent improvements. A number of studies showed that it holds its validity and works equally well in different cultures, communities and socio-demographic strata [M.W.Ross et al., 2010; Smolenski et al., 2010], including different European countries [Morell-Mengual et al. 2017; Tran et al. 2017].

Original English statements of the scale and their Ukrainian translations are given below in Tab.1. Answer options to each statement vary according to a seven-point scale from 1 ("Absolutely disagree") through 4 ("Can't decide") to 7 points ("Absolutely agree"). A possible option was also "It can't be applied to me" which considered to be a missed point. Although statements of feminine men are not always included, we believed it is better to use all the eight ones as it gave more stable models for checking scale validity.

We pointed out that internalized homonegativity is not a one-dimensional construct. In particular, SIHS consists of three interconnected, but separate measurements, reflected in two or three indicators (Table 1).

The value of the SIHS is calculated as the arithmetic mean of the responses to individual statements (the additive index is also possible). The answers to the two statements are pre-rotated (1 is transformed into 7, 2 is 6 , and so on).

One scale feature should be pointed out: its values' growth reflects an IH level decrease. It's easy to check reading the statements and answers options. To mitigate this inconvenience and not to rotate it we use the expression of "homosexuality acceptance" and its similar low IH synonyms. Moreover, only less than 4 points indicate IH presence. The SIHS value above 4 points testifies the opposite, that is, both own and others' homosexuality acceptance.

1 Within the framework of this study, IH relation to risky sexual behavior, access to HIV and MSM-service, as well as LGBT-activism were also evaluated. Relevant results can be found in Shestakovskyi \& Kasianczuk, 2018, Shestakovskyi et al, 2018. 


\section{Table 1}

\section{Short-Scale Internationalized Homonegativity Scale Formulation (SIHS)}

\begin{tabular}{|c|c|c|}
\hline IH level & Original Statements $^{a}$ & Ukrainian Translation $^{b}$ \\
\hline \multirow{3}{*}{$\begin{array}{l}\text { Comfortable } \\
\text { communication } \\
\text { with gays }\end{array}$} & $\begin{array}{l}\text { Obviously effeminate homosexual } \\
\text { men make me feel uncomfortable }\end{array}$ & $\begin{array}{l}\text { Відверто жінкуваті гомосексуа- } \\
\text { ли змушують мене ніяковіти }{ }^{R} \text {. }\end{array}$ \\
\hline & I feel comfortable in gay bars. & $\begin{array}{l}\text { Я почуваюся комфортно в } \\
\text { гей-барах. }\end{array}$ \\
\hline & $\begin{array}{l}\text { Social situations with gay men } \\
\text { make me feel uncomfortable }{ }^{R} \text {. }\end{array}$ & $\begin{array}{l}\text { Мені ніяково в присутності } \\
\text { геїв } R\end{array}$ \\
\hline \multirow{3}{*}{$\begin{array}{l}\text { Gay self-identity } \\
\text { personal comfort }\end{array}$} & $\begin{array}{l}\text { I feel comfortable being a } \\
\text { homosexual man. }\end{array}$ & $\begin{array}{l}\text { Бути гомосексуальним чо- } \\
\text { ловіком для мене комфортно. }\end{array}$ \\
\hline & $\begin{array}{l}\text { Homosexuality is morally } \\
\text { acceptable for me. }\end{array}$ & $\begin{array}{l}\text { Гомосексуальність є морально } \\
\text { прийнятна для мене. }\end{array}$ \\
\hline & $\begin{array}{l}\text { Even if I could change my sexual } \\
\text { orientation, I wouldn't }\end{array}$ & $\begin{array}{l}\text { Навіть якщо я міг би змінити } \\
\text { свою сексуальну орієнтацію, я } \\
\text { цього не зробив би. }\end{array}$ \\
\hline \multirow{2}{*}{$\begin{array}{l}\text { Open self-identi- } \\
\text { fication as gay }\end{array}$} & $\begin{array}{l}\text { I feel comfortable discussing } \\
\text { homosexuality in a public } \\
\text { situation }\end{array}$ & $\begin{array}{l}\text { Я спокійно почуваюся, коли } \\
\text { відкрито обговорюю гомосексу- } \\
\text { альність. }\end{array}$ \\
\hline & $\begin{array}{l}\text { I feel comfortable being seen in } \\
\text { public with an obviously gay } \\
\text { person. }\end{array}$ & $\begin{array}{l}\text { Я спокійно почуваюся, коли } \\
\text { мене бачать у компанії явно го- } \\
\text { мосексуальної людини. }\end{array}$ \\
\hline
\end{tabular}

${ }^{a}$ English statements source: [Tran et al., 2017].

${ }^{b}$ The translation is done within the framework of this study.

${ }^{R}$ The scale is rotated before the index is calculated.

\section{IH potential factors}

Higher IH usually involves lower openness to its orientation with others [Berg et al., 2015; Lingiardi et al., 2012; M.W.Ross et al., 2013; Rosser, Bockting, Ross, Miner, \& Coleman, 2008; Xu, Zheng, Xu, \& Zheng 2017]. MSM are (if any) in the coming out to a smaller number of people. The lower openness is often associated with worse access to HIV treatment and prevention, information and other health services for MSM.

Also, more homonegative MSM are less inclined to identify themselves as being exclusively homosexual and to be in a romantic relationship with other men [Berg et al., 2015; Hequembourg \& Dearing, 2013; Meyer \& Dean, 1998; Smolenski et al., 2010; Vu, Tun, Sheehy, \& Nel, 2012]. From the latter it follows that MSM who have permanent male sexual partners and / or live together with their regular partner should be less homosexual, and those who are married to a woman - more homosexual.

Studies in Ukraine and Estonia also confirm that IH is a characteristic of MSM who do not consider themselves gay and less share their homosexual traditions with others [Parker, Lõhmus, Mangine, \& Rüütel, 2016; Kasyanchuk, Trofimenko, Bilous, \& Sazonova, 2017]. 
With age, acceptance of homosexuality may appear, so it is expected that on average the older age will be associated with a lower IH [Berg et al., 2015; Lingiardi et al., 2012; Santos et al., 2013; Tran et al, 2017].

A higher level of education may be associated with a decreased IH due to greater awareness of homosexuality and a more favorable social environment [M.W.Ross et al., 2013, 2008; Shoptaw et al., 2009; Tran et al., 2017; Vu et al., 2012]. This is confirmed by studies in Ukraine [Kasyanchuk, Trofimenko, Bilous, \& Sazonova, 2017].

Living in smaller settlements - essentially outside big and more tolerant cities - contributes to a higher IH [M.W.Ross et al., 2013].

High religiosity may be associated with lower acceptance of homosexuality, especially given that the main denominations of the region are Christian and Islamic. If MSM residing in the region is religious, he has most likely learned negative religious views on homosexuality. See American studies [Barnes \& Meyer, 2012; Wilkerson, Smolensky, Brady, \& Rosser, 2012].

\section{Data and Methods}

Survey. A cross-sectional Internet survey was conducted in 2017 and covered MSM in 13 countries of the region. Data from 12 countries are analyzed (Armenia, Azerbaijan, Belarus, Estonia, Georgia, Kazakhstan, Kyrgyzstan, Lithuania, Macedonia, Moldova, Russia, Ukraine and Estonia).

The questionnaire was posted on the online survey service https://virtualexs.ru/. The link to the questionnaire was promoted through mobile applications and dating sites among gays: Hornet, BlueSystem.org, Grindr, as well as through partner websites and MSM-service community organizations.

Sample criteria for participation in the study included: self-identification as a man; having sex with men or being sexually attracted to men; permanent residence in one of the 13 countries of the study. The survey was allowed to be taken only one time.

The questionnaire was available in the languages of the listed countries, as well as in English. However, Russian language dominated among respondents (87\% filled out the questionnaire in Russian) not only in Russia but also in Belarus and Kazakhstan. Most of the answers in listed national languages were in the countries of the South Caucasus, Lithuania and Macedonia. In Ukraine, 64\% responded in Russian, 35\% - in Ukrainian, 1\% - in English. Obviously, in some countries, those MSM who do not identify themselves with Russians, to a large extent, were not included in the study.

Sample. An analytical sample contained 8239 people and was distributed among countries unevenly. The largest part of MSM sample was from Russia (5252 people), Ukraine (1365 people) and Belarus (495 people). Unfortunately, the coverage of the rest of the countries is much worse. Fewer than 100 people were interviewed in Macedonia, Moldova and Estonia. We merged Estonia with 
Lithuania and analyzed the sample of these two countries together ${ }^{1}$. In other countries around 100-200 participants were interviewed.

The design of the sample is so-called convenience sample (we sampled everyone who agreed to go through the survey). Therefore, it is not statistically representative sample of the MSM populations in the listed countries or in the whole of the EECA region. We do not know how it is possible to organize a strictly probabilistic, nationally representative sample in such a closed group. This method of sampling is quite common in modern MSM studies. Extrapolations, or very carefully extrapolated individual indicators (for example, the average level of IH) for all MSMs in a particular area should be avoided, possible systematic error should be taken into account. On the other hand, such a design still allows us to draw conclusions about the relation between individual variables and factors especially if the sample is large enough and varied.

In some countries, the vast majority of respondents have been recruited through social MSM organizations and are their employees. In particular, in Macedonia and Kyrgyzstan, $17 \%$ of respondents were employees of such organizations, 15\% - in Moldova, 10\% - in Armenia. In other countries, the respective share was $1-7 \%$. Employees of MSM-service organizations are more active, are more likely to accept their homosexuality, and have lower IH on average [Smolenski et al., 2010; Shestakovskyi \& Kasianczuk, 2018]. Therefore, the larger share of employees of MSM-organizations in the sample is, the lower IH level is shown in comparison with the entire population of MSM.

Variables. The short scale of internalized homonegativity was measured by expressing the level of agreement with the eight statements described above.

The sexual orientation was measured by a closed question: "Which variant best describes your perception of yourself? Who do you think you are?" Possible options: gay or homosexual, bisexual, natural or heterosexual, different term, I do not use any term / difficult to answer. The openness of homosexuality was estimated by answering the question: "If you think about all the familiar people (including family, friends, colleagues, neighbors etc.), how many of them know that you are attracted to men?" Answers were given on a five-point scale. They were grouped into three categories: all or more than a half, less than a half or some, and none. Respondents had to rate their own religiosity on a scale from 0 ("not a religious person at all") to 10 points ("very religious person"). The age was measured in full years. Responses on education level were grouped into three categories: full higher education (including a degree); elementary, incomplete or basic higher education; no higher education. The type of settlement has three categories during the analysis: the capital of the country, another big city (with a population of more than 100 thousand people), small towns and rural areas. The legal marriage status was reduced to a binary variable: whether married or not at the time of the survey. Actual cohabitation has four categories:

1 Both countries belong to the Baltic region and European Union, which may create similar conditions in the area of LGBT issues. The preliminary analysis also showed that the answers of respondents from Lithuania and Estonia have similar distributions. 
I live alone, I live with my female partner, I live with a male partner, or with non-sexual partners.

Methods. Descriptive analysis included one- and two-dimensional distribution of variables. The significance of differences between countries was estimated using Pearson $\chi^{2}$ criterion for nominal / ordinal variables, and Student t-test for intervals. The quality of the SIHS scale was evaluated using Cronbach's $\alpha$, and multi-group Confirmatory Factor Analysis (CFA).

We estimated reliability of Short Internalized Homonegativity Scale by Cronbach's $\alpha$. It allows us to show if a scale can be calculated as the arithmetic mean of the responses to its individual statements. At the same time, it less accurately takes into account the measurement error and does not take into account the possible multidimensionality of the tested construct. On the other hand, it is suitable for smaller samples, and the average arithmetic scale is easier to interpret.

Multi-Group CFA allows you to test the cross-national validity of the scale - its measurement invariance. It takes better account of the measurement error and verifies how the technique is equivalent between different language groups and countries, and allows you to use missed values. However, this method is technically more complex, requiring large samples, and the result is more difficult to interpret.

Multigroup CFA means that the factor model is tested simultaneously for several groups (in our case, countries). Such testing involves several stages. We will follow the bottom-up approach: first, establish a scale structure in individual countries, then consistently test ever more rigorous levels of measurement invariance [Byrne, 2013; Wang \& Wang, 2012]. The first level is the configural invariance, when the scale in all countries has the same structure of factors. Metric invariance implies the same factor loading in all countries without losing the quality of the model. This suggests that the scale, conventionally speaking, has the same "divisions". Therefore, it is possible to compare the relation force of SIHS between the countries and other factors. Depending on whether the factor loadings are on the indicators or on the factors of the first order, we are talking about the metric invariance of the first and second order respectively, which need to be tested separately. The next level of invariance is scalar, which implies equality of constants by factors in all countries without significant loss of model quality. It allows us to assume that the scale has the same "zero" in all countries, and therefore its average values can be compared with each other. We also need to establish scalar invariance of the first and second order. Since full metric or scalar invariance involves too restrictive constraints of models, often have to weaken them to partial invariance, that is, when factor loadings or constants are established evenly for some indicators, at least two [Byrne, Shavelson, \& Muthén, 1989]. Establishing a complete or at least partial invariance is our aim. At first, we tested the levels of invariance only for six countries, excluding Russia and Ukraine. The latter have relatively large samples and can therefore obscure the differences between the validity of the scale in other countries. After establishing a measure of scalar invariance, we added models to Russia and Ukraine and checked them again.

To compare models of varying invariance levels among themselves, the comparison of the $\chi^{2}$ criteria was also initially used, but again there is a problem asso- 
ciated with a large sample. Therefore, we use the difference in CFI ( $\triangle \mathrm{CFI})$, which should not exceed 0.01 for the configuration and metric, or metric and scalar models.

The relation between SIHS and socio-demographic factors was tested by modeling by structural equations, where the dependent variable was the value of the latent factor of the SIHS, and not the arithmetic mean. In this case, we were not more interested in it, but in the estimation of the connections, which in this case is more accurate, because it takes into account the measurement error of the SIHS. The evaluation algorithms and model quality statistics were the same as for the CFA.

The statistical analysis was performed in IBM SPSS Statistics 22.0 [SPSS, 2013] and Mplus 7.0 [Muthén \& Muthén, 2012].

\section{Results}

\section{Socio-demographic characteristics of respondents}

Most of the respondents (64\%) identify themselves as gay or homosexuals, $27 \%$ as bisexual, $2 \%$ as heterosexuals, the rest prefer to use another term. This relation is different in different countries. The largest share of gays, more than $70 \%$, was in European countries - Lithuania, Estonia and Macedonia. The least - in Armenia (43\%), Azerbaijan, Georgia and Kyrgyzstan (there were also many of those who could not decide which term applicable to them, $16 \%$ in Armenia). The distribution in the rest of the countries corresponded to the overall distribution.

As for the openness about their sexual orientation the respondents are placed as followed: the most open - Lithuanians and Estonians (from 17 to $22 \%$ said that everybody knows it, and from 25 to $29 \%$, that more than a half of their mates know about it ). More closed are MSMs in Armenia and Azerbaijan, while in the rest of the world more than a half of them answered that few people know about their attraction to men, or nobody knows about it.

The median age of respondents is 30 years, while half of them belong to the age group from 24 to 37 , and $80 \%$ are younger than 40 years. Age characteristics of respondents differ in different countries. In particular, in Armenia, Azerbaijan, Georgia, Kyrgyzstan, respondents are younger on average, while in Estonia, Lithuania and Russia they are older.

$72 \%$ have higher education, among them one third - incomplete higher education, and 37\% - full higher education. Education varies across countries. The largest proportion of respondents with higher education in the sample are from Ukraine (78\%), and the smallest - from Azerbaijan and Kazakhstan.

Most of those who participated in the study were never officially married: from $75 \%$ in Kyrgyzstan to $92 \%$ in Macedonia. At the same time, the answers about cohabitants give a slightly different picture: one third lives with parents, another $27 \%$ - separately; $16 \%$ live with a male partner, $11 \%$ - with his wife or female partner. The situation is different in some countries: a significant part of MSM lives with a male partner in Macedonia (37\%), Lithuania and Estonia (24\%), 13-17\% in Moldova, Belarus, Ukraine and Russia. The smallest proportion of MSM who lives with male partners was in Azerbaijan and Georgia. 
Most of the respondents are residents of big cities (100 thousand and more). In all countries only a few percent of respondents live in rural areas.

Thus, the main part of the respondents are young, educated, urban residents, most of whom have never been in an official heterosexual marriage, but a significant part at the time of the study lived with a male partner.

\section{SIHS reliability checking and constructive validation}

In each country, Cronbach's $\alpha$ test reports a sufficient $(>0.7)$ or good $(>0.8)$ SIHS consistency (Table 2). The average is 0.75 .

Table 2

SIHS consistency indicators for separate countries

\begin{tabular}{|l|r|c|}
\hline Country & \multicolumn{1}{|c|}{ N } & Cronbach's $\alpha$ \\
\hline Russia & 3830 & 0.71 \\
\hline Belarus & 348 & 0.71 \\
\hline Azerbaijan & 74 & 0.71 \\
\hline Ukraine & 1001 & 0.71 \\
\hline Kazakhstan & 165 & 0.72 \\
\hline Armenia & 76 & 0.74 \\
\hline Moldova & 39 & 0.77 \\
\hline Kyrgyzstan & 130 & 0.79 \\
\hline Macedonia & 39 & 0.79 \\
\hline Estonia/ Lithuania & 168 & 0.81 \\
\hline Georgia & 96 & 0.83 \\
\hline
\end{tabular}

The measurement invariance using CFA was tested in ten countries where the sample exceeded 100 respondents - or nine groups, taking into account the sample consolidation of Lithuania and Estonia. They did not include Macedonia and Moldova ${ }^{1}$.

We began with the theoretical scale structure in separate countries. First, for each country, a three-factor model was evaluated in accordance with the theoretical scale structure (Table 1). Each latent factor of the first order had 2-3 statements as indicators. In its turn, the factors of the first order formed one latent factor of the second order, the value of which was SIHS, cleared of the measurement error. The consensus statistics for these models are shown in Table. 3

1 We also tested the equivalence of measurements between separate languages in separate countries, but the presentation of the results goes beyond the scope of the article. It should be noted that the full scalar invariance of the Russian-language version of the scale in Russia, Ukraine, Belarus, and Kazakhstan was established, as well as more or less partial scalar invariance between them and the Russian-speaking scale in Kyrgyzstan, Ukrainian-language in Ukraine, as well as the scale in the Lithuanian and Georgian languages in the listed countries. For more information, see (Shestakovskyi \& Kasianczuk, 2018), Appendix A. 
Table 3

\section{Consensus statistics for single-group CFA SIHS models for separate countries}

\begin{tabular}{|c|c|c|c|c|c|c|c|c|}
\hline No. & Country & $\mathbf{N}$ & $\begin{array}{c}\text { MLR } \chi^{2} \\
\text { (deg. free.) }\end{array}$ & $\begin{array}{c}\text { St.sign. } \\
\chi^{2}\end{array}$ & RMSEA & CFI & TLI & SRMR \\
\hline 1 & Azerbaijan & 117 & $34.845(17)$ & 0.007 & 0.095 & 0.875 & 0.793 & 0.070 \\
\hline 2 & $\begin{array}{l}\text { Azerbaijan - } \\
\text { additional model }^{a}\end{array}$ & 117 & $21.904(16)$ & 0.146 & 0.056 & 0.958 & 0.927 & 0.061 \\
\hline 3 & Armenia & 137 & $33.572(17)$ & 0.010 & 0.084 & 0.878 & 0.800 & 0.067 \\
\hline 4 & $\begin{array}{l}\text { Armenia - } \\
\text { one-factor model }^{b}\end{array}$ & 137 & $36.128(20)$ & 0.015 & 0.077 & 0.882 & 0.834 & 0.069 \\
\hline 5 & $\begin{array}{l}\text { Armenia - } \\
\text { two-factor model }\end{array}$ & 137 & $25.314(19)$ & 0.151 & 0.049 & 0.954 & 0.932 & 0.056 \\
\hline 6 & Belarus & 492 & $39.574(17)$ & 0.002 & 0.052 & 0.950 & 0.918 & 0.039 \\
\hline 7 & Georgia $^{d}$ & 148 & $20.560(18)$ & 0.302 & 0.031 & 0.987 & 0.979 & 0.047 \\
\hline 8 & Kazakhstan & 222 & $26.571(17)$ & 0.065 & 0.050 & 0.955 & 0.927 & 0.046 \\
\hline 9 & Kyrgyzstan & 181 & $22.613(17)$ & 0.162 & 0,043 & 0,978 & 0,963 & 0,044 \\
\hline 10 & Lithuania / Estonia & 197 & $22.503(17)$ & 0.166 & 0,041 & 0.982 & 0,970 & 0.034 \\
\hline 11 & Russia $^{e}$ & 5212 & $130.678(16)$ & $<0.001$ & 0.037 & 0.977 & 0.960 & 0.019 \\
\hline 12 & Ukraine $^{e}$ & 1350 & $31.954(16)$ & 0.01 & 0,027 & 0.987 & 0.978 & 0.020 \\
\hline
\end{tabular}

a Factor dispersion "Gay self-identity personal comfort" was put as zero. Two covariations of residual dispersions between the statements "I feel comfortable discussing homosexuality in a public situation" and "Obviously effeminate homosexual men make me feel uncomfortable" (average negative correlation), and between the statements "To be homosexual for me is comfortable" and "I feel comfortable being seen in public with an obviously gay person"(a weak positive correlation).

$b$ One-level model without three SIHS subscales.

c One-level model with two distinguished factors from hypothetical variables.

$d$ "Open Self-Identification" factor was dispersed to zero.

$e$ Added residual dispersions covariance between the statements "Obviously effeminate homosexual men make me feel uncomfortable" and "I feel comfortable being seen in public with an obviously gay person" (a very weak negative correlation).

For five countries, it was necessary to make changes in the ascending model. For Armenia, in general, it was not possible to build a stable three-factor model. One-and two-factor models (Table 3, No. 3 and $4^{1}$ ) have a structure different from the theoretical one. Therefore, Armenian data at this SIHS stage showed nonequivalence. In the case of Azerbaijan, the initial model had an unsatisfactory RMSEA (Model 1), and in the case of Georgia, the stable model was not obtained (the correlation between factors of the first order exceeded 1). Therefore, in both

1 Here and below the table is indicated only at the first mention, then only the model number in the table is indicated. 
cases, it was necessary to fix the dispersion of one of the factors of the first order as zero, and in the case of Georgia, to add two correlations between the residual dispersion indicators (No. 2 and 7). The theoretical models for Russia and Ukraine had quite decent consensus statistics, and could be used as they are. But we decided to add one weak correlation between the final dispersion indicators as it improved the model quality.

For the nine countries (without Armenia and with the consolidated samples of Lithuania and Estonia), we tested multi-group factor models with increasing restrictions, which had to demonstrate the SIHS measurement equivalence in different countries. Initially, equivalence was established in six countries (excluding Russia and Ukraine), then similar models were tested for all countries. The consensus statistics is given in Table. 4

Table 4

\section{Consensus statistics for multigroup CFA for SHIS models with different invariance level}

\begin{tabular}{|c|c|c|c|c|c|c|c|}
\hline No. & Invariance model ${ }^{a}$ & CFI & $\begin{array}{l}\text { Diff. } \\
\text { CFI }\end{array}$ & TLI & RMSEA & $\begin{array}{l}\text { MLR } \chi^{2} \\
\text { (st. sign., } \\
\text { p.val.) }\end{array}$ & $\begin{array}{l}\text { Adjust. diff. } \\
\text { MLR } \chi^{2} \\
\text { (st. sign.) }\end{array}$ \\
\hline \multicolumn{8}{|c|}{6 countries (excluding Russia \& Ukraine) } \\
\hline 13 & Configurative & 0,967 & - & 0,946 & 0,047 & $\begin{array}{c}153,658 \\
(102,1,0895) \\
\end{array}$ & - \\
\hline 14 & Metric & 0,941 & $0,026^{g}$ & 0,922 & 0,057 & $\begin{array}{c}153,658 \\
(127,1,1013)\end{array}$ & $\begin{array}{c}65,049 \\
(<0,001)\end{array}$ \\
\hline 15 & Partial metric $^{b}$ & 0,957 & $0,010^{g}$ & 0,941 & 0,049 & $\begin{array}{c}192,539 \\
(124,1,1057)\end{array}$ & $\begin{array}{l}38,516 \\
(0,016)\end{array}$ \\
\hline 16 & Metric of 2-order & 0,953 & $0,014^{g}$ & 0,941 & 0,049 & $\begin{array}{c}208,023 \\
(134,1,0986)\end{array}$ & $\begin{array}{l}54,207 \\
(0,008)\end{array}$ \\
\hline 17 & $\begin{array}{l}\text { Partial metric of } \\
\text { 2-order }\end{array}$ & 0,958 & $0,009^{g}$ & 0,948 & 0,047 & $\begin{array}{c}198,504 \\
(133,1,0956)\end{array}$ & $\begin{array}{l}44,879 \\
(0,051)\end{array}$ \\
\hline 18 & Scalar & 0,921 & $0,037^{h}$ & 0,916 & 0,059 & $\begin{array}{c}282,409 \\
(158,1,0777)\end{array}$ & $\begin{array}{c}88,421 \\
(<0,001)\end{array}$ \\
\hline 19 & Partial scalard & 0,951 & $0,007^{h}$ & 0,947 & 0,047 & $\begin{array}{c}233,618 \\
(156,1,08)\end{array}$ & $\begin{array}{l}35,186 \\
(0,050)\end{array}$ \\
\hline 20 & Scalar of 2-order & 0,906 & $0,052^{h}$ & 0,905 & 0,063 & $\begin{array}{c}314,382 \\
(166,1,0751) \\
\end{array}$ & $\begin{array}{l}121,424 \\
(<0,001)\end{array}$ \\
\hline 21 & $\begin{array}{l}\text { Partial scalar of } \\
\text { 2-ordere }\end{array}$ & 0,950 & $0,008^{h}$ & 0,948 & 0,046 & $\begin{array}{c}241,939 \\
(163,1,0764)\end{array}$ & $43,320(0,055)$ \\
\hline \multicolumn{8}{|c|}{8 countries (including Russia \& Ukraine) } \\
\hline 22 & Configurative & 0,976 & - & 0,961 & 0,037 & $\begin{array}{c}318,210 \\
(134,1,0974) \\
\end{array}$ & - \\
\hline 23 & Partial metric ${ }^{b}$ & 0,973 & $0,003^{i}$ & 0,964 & 0,036 & $\begin{array}{c}377,647 \\
(166,1,1138) \\
\end{array}$ & $\begin{array}{l}60,398 \\
(0,002)\end{array}$ \\
\hline 24 & $\begin{array}{l}\text { Partial metric of } \\
2 \text {-orderc }\end{array}$ & 0,973 & $0,003^{i}$ & 0,966 & 0,035 & $\begin{array}{c}391,82 \\
(179,1,1058)\end{array}$ & $74,346(0,004)$ \\
\hline 25 & Partial scalard & 0,963 & $0,010^{j}$ & 0,961 & 0,037 & $\begin{array}{c}502,426 \\
(212,1,0833)\end{array}$ & $\begin{array}{c}115,478 \\
(<0,001)\end{array}$ \\
\hline 26 & $\begin{array}{l}\text { Partial scalar of } \\
\text { 2-order } f\end{array}$ & 0,966 & $0,007^{j}$ & 0,966 & 0,035 & $\begin{array}{c}487,881 \\
(222,1,0819)\end{array}$ & $\begin{array}{c}96,257 \\
(<0,001)\end{array}$ \\
\hline
\end{tabular}


a The removed restrictions in models of lower invariance level remain in the following models. For example, Model No. 16 retains the parameters of partial invariance of Model No. 15.

$b \quad$ Factor loading equality restriction was removed for the statement "I feel comfortable being seen in public with an obviously gay person" in Georgia and Kyrgyzstan, and "Homosexuality is morally acceptable for me" in Kyrgyzstan.

$c$ Factor loading equality restriction was removed for the statement "Homosexuality is morally acceptable for me" in Azerbaijan.

$d$ Constant equality restriction was removed for the statement "I feel comfortable in gay bars" in Georgia and "I feel comfortable discussing homosexuality in a public situation" in Lithuania / Estonia.

$e$ The restriction for zero constant equality was removed for the subscale "Comfortable communication with gays" in Georgia and also constant equality restriction was partially removed for the statement "I feel comfortable being seen in public with an obviously gay person" in Lithuania / Estonia and "Obviously effeminate homosexual men make me feel uncomfortable" in Azerbaijan.

$f$ The restrictions on the equality of zero for the constant "Comfortable communication with gays" for Georgia were lifted, as well as the restrictions on equality of constants for the items "II feel comfortable being seen in public with an obviously gay person" for Lithuania / Estonia and "Obviously effeminate homosexual men make me feel uncomfortable" in Azerbaijan and Russia.

g Comparison with CFI Models No. 13.

$h$ Comparison with CFI Models No. 17.

i Comparison with CFI Models No. 22.

j Comparison with CFI Models No. 24.

Initially, the final single-group models for six countries were merged into one model with a configuration invariance (Table 4, No. 13). The model demonstrated that in all included SIHS countries had the same three-factor structure. The first-order metric factors model (No. 14) showed a significant deterioration of the CFI indicator (by 0.01) compared to the configuration model. Therefore, it was necessary to remove restrictions on equality factor loading by three indicators in two countries (Georgia and Kyrgyzstan). Setting metric invariance of the second order (No. 16-17), the restriction from one indicator for Azerbaijan was removed between the values of the latent SIHS factor for each of the three factors for separate measurements.

The model with the first-order scalar invariance (No. 18) showed a noticeable CFI deterioration in comparison with partial metric model (No. 17). Therefore, we had to remove constants equality restrictions for two indicators in two countries (No. 19). When establishing a second-order scalar invariance for SIHS factor, it was necessary to remove one more indicator from constants limits in two countries in order to obtain consensus statistics model (No. 20-21).

The testing of different invariance levels for the eight countries (No. 22-26) yielded almost identical results. Additionally, it was necessary to remove the restriction of constants equality for one indicator in Russian data (No. 26).

Thus, SIHS showed a partial scalar invariance for nine countries in total. The invariance level is different for certain countries. Full scalar invariance is preserved for SIHS in Ukraine, Belarus, and Kazakhstan, and in Russia it has a scalar invariance for 7 of 8 statements. For other countries, the scalar invariance re- 
mains for the number of statements from 3 to 6 (between Georgia and Lithuania / Estonia).

Internalized homonegativity level. The scale ranges from 1 to 7 points, where 1 indicates the highest level of internalized homophobia, and 7 indicates the highest level of acceptance of homosexuality. Scores are significantly higher than 4 in all countries (Figure). On average, the surveyed MSM rather accept homosexuality. The difference in the average indices between countries is not large: it is 1.2 points difference between the highest scoring country (Macedonia) and the lowest one (Kyrgyzstan). Russian Federation, representing 64\% of the sample, has the shortest IH confidence interval, which is significantly different from the average level of IH among respondents from Europe (Belarus, Estonia, Lithuania, Macedonia, and Ukraine).

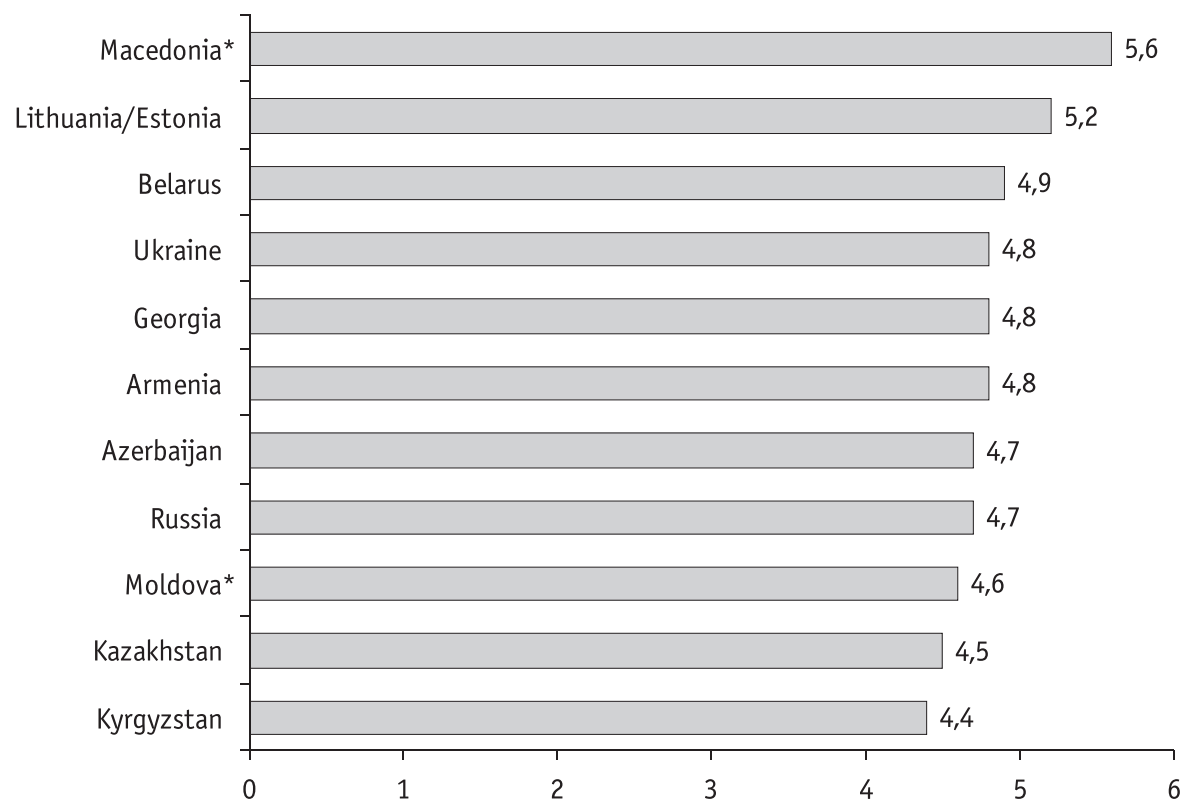

Figure. The mean values of SIHS scale in 12 countries (in the listed countries $*, N<100$ ): 1 is the maximum IH level, and 7 is the maximum acceptance of one's own homosexuality.

Differences from 4 (absence of both homonegativity and acceptance) are statistically significant at the level of $p<0.001$

\section{IHfactors modeling}

Since the samples in the countries covered by the study have certain peculiarities, the existence of statistical links with their coverage in each country is worth checking. The analysis includes 9 countries where we have previously made a multi-group CFA.

Two-dimensional relation. Table 5 depicts the regression parameters between the latent scores of the SIHS and their predictors for each country. 
Table 5

\section{Unstandardized coefficients of bivariate regressions by country. SIHS latent factor score is a dependent variable}

\begin{tabular}{|c|c|c|c|c|c|c|c|c|}
\hline & $\begin{array}{l}\text { Azer- } \\
\text { baijan }\end{array}$ & Belarus & $\begin{array}{r}\text { Lithuania } \\
\text { /Estonia }\end{array}$ & Georgia & $\begin{array}{c}\text { Kazakh- } \\
\text { stan }\end{array}$ & $\begin{array}{c}\text { Kyrgyz- } \\
\text { stan }\end{array}$ & Russia & Ukraine \\
\hline $\mathrm{N}$ & 116 & 491 & 192 & 147 & 217 & 175 & 5074 & 1329 \\
\hline \multicolumn{9}{|c|}{ Sexual orientation $($ Ref. $=$ Gay $)$} \\
\hline Bisexual & $-0.83^{*}$ & $-0.37 * * *$ & $-1.23 * * *$ & $-0.79 *$ & $-0.88^{*}$ & $-1.21 * * *$ & $-1.15^{* * *}$ & $-1.08 * * *$ \\
\hline $\begin{array}{l}\text { Other (incl. } \\
\text { heterosexual) }\end{array}$ & $-1.87 * * *$ & $-0.30 * * *$ & $-1.66^{* * *}$ & $-1.02^{*}$ & -0.86 & $-1.62^{* * *}$ & $-1.34 * * *$ & $-1.52^{* * *}$ \\
\hline \multicolumn{9}{|c|}{ How many know about one's SO $($ Ref. $=$ None $)$ : } \\
\hline $\begin{array}{l}\text { A few / Less } \\
\text { than half }\end{array}$ & $1.05^{*}$ & $0.93^{* * *}$ & $0.95^{* *}$ & $0.69^{*}$ & $0.92^{* * *}$ & $1.02^{* *}$ & $0.89 * * *$ & $0.84^{* * *}$ \\
\hline $\begin{array}{l}\text { All / More } \\
\text { than half }\end{array}$ & 0.65 & $1.74^{* * *}$ & $1.84^{* * *}$ & $1.99 * * *$ & $2.15^{* * *}$ & $2.20 * * *$ & $1.77 * * *$ & $1.79^{* * *}$ \\
\hline \multicolumn{9}{|c|}{ Place of residence $($ Ref. $=$ Capital city $)$} \\
\hline $\begin{array}{l}\text { Other large } \\
\text { city }\end{array}$ & $-1.01^{*}$ & -0.07 & -0.19 & -0.27 & 0.39 & -0.85 & $-0.33^{* * *}$ & $-0.34^{* * *}$ \\
\hline $\begin{array}{l}\text { Small } \\
\text { town/village }\end{array}$ & $-1.20^{*}$ & $-0.42^{*}$ & -0.32 & -0.28 & -0.10 & $-1.19^{* *}$ & $-0.40 * * *$ & $-0.61^{* * *}$ \\
\hline \multicolumn{9}{|c|}{ Education (Ref. = Completed higher education) } \\
\hline $\begin{array}{l}\text { Incomplete } \\
\text { higher educa- } \\
\text { tion }\end{array}$ & 0.06 & -0.01 & -0.22 & 0.40 & 0.11 & -0.11 & 0.03 & 0.07 \\
\hline None & -0.19 & -0.08 & $-0.55^{*}$ & 0.62 & $0.60^{*}$ & 0.06 & 0.09 & -0.01 \\
\hline $\begin{array}{l}\text { Married } \\
(1=\text { yes })\end{array}$ & -0.61 & -0.26 & 0.09 & 0.59 & -0.07 & $-1.11^{* *}$ & $-0.46^{* * *}$ & $-0.47 * *$ \\
\hline \multicolumn{9}{|c|}{ Cohabitation (Ref. $=$ Not with sexual partners) } \\
\hline Live alone & -0.05 & -0.02 & -0.05 & 0.27 & -0.04 & -0.27 & 0.001 & 0.19 \\
\hline $\begin{array}{l}\text { With wife/fe- } \\
\text { male partner }\end{array}$ & -0.34 & -0.56 & -1.19 & 0.12 & -0.69 & $-0.88^{*}$ & $0.60^{* * *}$ & $-0.45^{* *}$ \\
\hline $\begin{array}{l}\text { With male } \\
\text { partner }\end{array}$ & $2.03^{* * *}$ & $0.47^{*}$ & $0.63^{*}$ & 0.99 & 0.36 & $0.69 * * *$ & $0.64^{* * *}$ & $0.63^{* * *}$ \\
\hline Age, years & 0.01 & 0.01 & 0.01 & $-0.03 *$ & -0.01 & $-0.04^{* *}$ & $0.01 * * *$ & 0.01 \\
\hline $\begin{array}{l}\text { Religiosity } \\
(0-10 \text { points, } \\
10=\text { very reli- } \\
\text { gious })\end{array}$ & $-0.12^{*}$ & $-0.09 * *$ & -0.06 & $-0.51 * * *$ & $-0.19 *$ & 0.09 & $-0.06^{* * *}$ & $-0.08 * * *$ \\
\hline
\end{tabular}

Ref. - category of variable with which the effect of other categories is compared.

Significance of coefficients: $* p=0.05 ; * * p=0.01 ; * * p=0.001$

In all countries, bisexual or other (including heterosexual) sexual orientation is associated with higher internalized homonegativity, so does a greater degree of concealment of own sexual orientation. The only exception is the "other" orientation in Kazakhstan and the situation where all or more than a half of respondents' mates know about their sexual orientation (in Azerbaijan). 
In six of the eight countries (except Georgia and Kazakhstan), living with a male partner is significantly associated with lower IH (the reference category here is cohabitation with parents, relatives, or acquaintances).

In Kazakhstan, Kyrgyzstan, Russia and Ukraine those living with female partner had on average higher homonegativity.

Non-residents of the capital of Azerbaijan, Russia or Ukraine showed an average higher IH rate.

Age was associated with IH only for Georgia, Kyrgyzstan and Russia, and in the latter case, an older age was associated with a higher acceptance of homosexuality.

A significant difference in $\mathrm{IH}$ between respondents who completed higher education and those without any higher education was observed in Lithuania/Estonia and Kazakhstan only. However, in Kazakhstan, those with lower education have lower homonegativity.

Multi-dimensional model. We included significant predictors from the previous stage into SEM models with multiple independent variables. The results are presented in Table 6.

\section{Table 6}

\section{Unstandardized coefficients of multiple regressions by country. SIHS latent factor score is a dependent variable}

\begin{tabular}{|c|c|c|c|c|c|c|c|c|}
\hline & $\begin{array}{l}\text { Azer- } \\
\text { baijan }\end{array}$ & Belarus & $\begin{array}{c}\text { Lithuania } \\
\text { /Estonia }\end{array}$ & Georgia & $\begin{array}{c}\text { Kazakh- } \\
\text { stan }\end{array}$ & $\begin{array}{c}\text { Kyrgyz- } \\
\text { stan }\end{array}$ & Russia & Ukraine \\
\hline $\mathrm{N}$ & 116 & 491 & 192 & 147 & 217 & 175 & 5074 & 1329 \\
\hline \multicolumn{9}{|c|}{ Sexual orientation $($ Ref. $=$ Gay) } \\
\hline Bisexual & -0.67 & $-0.29 * * *$ & $-0.74^{*}$ & -0.32 & -0.33 & $-0.77^{*}$ & $-0.23^{* * *}$ & $-0.58 * * *$ \\
\hline $\begin{array}{l}\text { Other (incl. } \\
\text { hetero- } \\
\text { sexual) }\end{array}$ & $-1.52^{* *}$ & $-0.24^{* * *}$ & $-1.30^{*}$ & -0.50 & -0.33 & -0.91 & $-0.19 * * *$ & $-0.98^{* * *}$ \\
\hline \multicolumn{9}{|c|}{ How many know about one's SO (Ref. = None $)$} \\
\hline $\begin{array}{l}\text { A few / } \\
\text { Less than } \\
\text { half }\end{array}$ & 0.60 & $0.30 * * *$ & 0.38 & 0.51 & $1.10^{* * *}$ & $0.77^{*}$ & $0.24 * * *$ & $0.62 * * *$ \\
\hline $\begin{array}{l}\text { All / More } \\
\text { than half }\end{array}$ & 0.23 & $0.44^{* * *}$ & $1.05^{*}$ & $1.39^{* * *}$ & $2.15^{* * *}$ & $1.75^{* * *}$ & $0.41 * * *$ & $1.42^{* * *}$ \\
\hline \multicolumn{9}{|c|}{ Place of residence $($ Ref. $=$ Capital city $)$} \\
\hline $\begin{array}{l}\text { Other large } \\
\text { city }\end{array}$ & -0.79 & - & - & - & - & -0.25 & $-0.06^{* *}$ & -0.14 \\
\hline $\begin{array}{l}\text { Small } \\
\text { town/ } \\
\text { village }\end{array}$ & -0.84 & - & - & - & - & -0.69 & -0.02 & -0.18 \\
\hline \multicolumn{9}{|c|}{ Education $($ Ref. $=$ Completed higher education $)$} \\
\hline $\begin{array}{l}\text { Incomplete } \\
\text { higher } \\
\text { education }\end{array}$ & - & - & -0.24 & - & 0.26 & - & $0.05^{* *}$ & - \\
\hline None & - & - & -0.29 & - & $0.55^{*}$ & - & $0.09 * * *$ & - \\
\hline $\begin{array}{l}\text { Married } \\
(1=\text { yes })\end{array}$ & - & - & - & - & - & 0.18 & - & - \\
\hline
\end{tabular}


End of Table 6

\begin{tabular}{|c|c|c|c|c|c|c|c|c|}
\hline & $\begin{array}{l}\text { Azer- } \\
\text { baijan }\end{array}$ & Belarus & $\begin{array}{c}\text { Lithuania } \\
\text { /Estonia }\end{array}$ & Georgia & $\begin{array}{c}\text { Kazakh- } \\
\text { stan }\end{array}$ & $\begin{array}{c}\text { Kyrgyz- } \\
\text { stan }\end{array}$ & Russia & Ukraine \\
\hline \multicolumn{9}{|c|}{ Cohabitation (Ref. $=$ Not with sexual partners) } \\
\hline Live alone & -0.06 & -0.01 & -0.12 & - & - & - & -0.02 & 0.05 \\
\hline $\begin{array}{l}\text { With } \\
\text { wife/female } \\
\text { partner }\end{array}$ & 0.29 & 0.06 & -0.59 & - & - & - & -0.01 & 0.14 \\
\hline $\begin{array}{l}\text { With male } \\
\text { partner }\end{array}$ & $1.27^{* *}$ & 0.04 & 0.25 & - & - & - & $0.08^{* * *}$ & 0.20 \\
\hline Age, years & - & - & - & $-0.03^{*}$ & - & $-0.05^{* * *}$ & $0.11^{* * *}$ & $0.01^{*}$ \\
\hline $\begin{array}{l}\text { Religiosity } \\
(0-10 \\
\text { points, } \\
10=\text { very } \\
\text { religious })\end{array}$ & - & $-0.12^{*}$ & - & $-0.15^{* *}$ & $-0.15^{* * *}$ & - & $-0.10^{* * *}$ & $-0.06^{* *}$ \\
\hline
\end{tabular}

Ref. - category of variable with which the effect of other categories is compared.

Significance of coefficients: ${ }^{*} p=0.05 ; * * p=0.01 ; * * * p=0.001$

Most of the countries hold significant associations with sexual orientation and its openness.

Significant associations between IH and cohabitation with a male partner is retained only in Russia and Azerbaijan. Moreover, significant associations with the type of residence (capital or other city or village) have almost disappeared, that can be explained mainly by the access to MSM community infrastructure, higher readiness for openness among the residents of the capital and, accordingly, it is more probable for the inhabitants of the capital to be in the circle of "similar orientation people" and to have a male partner.

The association between age and $\mathrm{IH}$ retained its significance and direction in Georgia, Kyrgyzstan and Russia, and became significant for Ukraine. There is an education level association with IH level in Kazakhstan and Russia: lower education is associated with lower IH.

\section{Discussion}

Thus, SIHS demonstrated its validity in all studied countries. The scale consensus for all countries varies from satisfactory to good. If seeking more substantiated cross-national comparisons, then in nine countries (except Armenia, as well as Macedonia and Moldova), SIHS showed higher or lower scalar equivalence, that is its possibility to be used for comparison of scale values and their relation with other variables.

A different measure of cross-national validity between separate countries, as well as the need to make changes to initial one-group models, may be caused in the first place by a small sample in separate countries. In addition, translation into different languages could also bring some non-equivalence.

Basing on the data from Azerbaijan, Belarus, Lithuania / Estonia, Georgia, Kazakhstan, Kyrgyzstan, Russia and Ukraine, it was shown that despite the gen- 
erally good situation regarding the acceptance of homosexuality among MSM in the EECA region, the situation is different in some countries - respondents from European subregion (Belarus, Estonia, Lithuania, Macedonia, Ukraine) show a lower IH level, while the MSM from Moldova, Russia, the countries of the South Caucasus and Central Asia have higher IH level. It is noticed that the rights equality index for LGBT is different for these countries: the average index in Belarus, Ukraine, Estonia, Lithuania and Macedonia is 16, while in Azerbaijan, Armenia, Moldova and Russia (for Central Asian countries this index is not calculated) it is equal to $8^{1}$. Thus, our data are consistent with the literature data on the higher level of self-stigmatization of LGBT in societies where homophobic attitudes are widespread [Berg, Munthe-Kaas, \& Ross, 2016; M. W. Ross \& Rosser, 1996].

Thus, on the basis of data obtained in Azerbaijan, Belarus, Lithuania / Estonia, Georgia, Kazakhstan, Kyrgyzstan, Russia and Ukraine it was shown that the main sociodemographic variables associated with the IH level are sexual orientation (heterosexual and bi-sexual men tend to accept less their romantic feelings to other men than homosexuals), openness about their own homosexuality to other people (respondents with lower IH are more likely to be open to others about it), living together with male partner (the respondents who lived with a male partner better accept their own homosexuality), age (in Ukraine and Russia IH level decreases with age, while in Georgia and Kyrgyzstan older respondents showed higher internal homophobia) and education level (in Estonia and Lithuania lack of higher education is associated with higher IH, whereas in Kazakhstan and Russia, on the contrary, lack of higher education is associated with lower IH). In two-dimensional models, the significance of the type of settlement was also evident (inhabitants of the capital were characterized by lower IH levels in comparison with residents of other towns or villages).

In general, gays and those who accept better their own homosexual attractions (and therefore on the average do not often hide their homosexuality or live with male partner), have lower IH. Also, the latter implies lower religiousness. This coincides with the results of Western studies quoted above.

However, age and education are related to IH in some countries in a paradoxical way: in Western literature (as well as in one of the previous studies in Ukraine) it is noted that with age and higher level of education the acceptance level of homosexuality is higher, however in Georgia and Kyrgyzstan, older respondents accept worse their homosexuality, and in Kazakhstan and Russia, less educated people perceive their homosexuality easier than those who have higher education.

\section{Conclusions}

A systematic comparative study of the level of internalized homonegativity among homosexual and bisexual men was conducted for the first time in the Eastern Europe and Central Asia region.

1 See. https://rainbow-europe.org/country-ranking. 
We have received a quite well working and practically applicable scale for measuring internalized homonegativity in the languages of listed countries. For some countries, adaptation of such a technique has been made for the first time, and it has also been proved for the first time that the scale is consistent and more or less cross-nationally valid.

It is shown that the average IH level in all studied countries is rather low, but there are differences between countries regarding the level of internal homophobia of respondents and socio-demographic factors associated with it. In most countries the factors significantly related to IH were following: sexual orientation and openness of their own homosexual feelings to others. In the presence of these variables, joint residence with a regular partner and type of settlement may lose their significant value. The relation between IH and education is also found, but the nature of this relation in some countries is different from that described in Western European studies.

Since internalized homonegativity is an important factor for gays' and other MSM's health, this research, including the adapted scale, will help to determine the impact of this factor and to develop methods of reducing its negative impact.

\section{References}

Barnes, D. M., \& Meyer, I. H. (2012). Religious affiliation, internalized homophobia, and mental health in lesbians, gay men, and bisexuals. The American Journal of Orthopsychiatry, 82(4), 505-515. https://dx.doi.org/10.1111/j.1939-0025.2012.01185.x.

Bell, A. P., \& Weinberg, M. S. (1978). Homosexualities: a study of diversity among men and women. New York, NY: Simon \& Schuster.

Berg, R. C., Lemke, R., \& Ross, M. W. (2017). Sociopolitical and cultural correlates of internalized homonegativity in gay and bisexual men: findings from a Global Study. International Journal of Sexual Health, 29(1), 97-111. https://dx.doi.org/10.1080/19317611.2016.1247125.

Berg, R. C., Munthe-Kaas, H. M., \& Ross, M. W. (2016). Internalized homonegativity: a systematic mapping review of empirical research. Journal of Homosexuality, 63(4), 541-558. https://dx.doi.org/10.1080/00918369.2015.1083788.

Berg, R. C., Ross, M. W., Weatherburn, P., \& Schmidt, A J. (2013). Structural and environmental factors are associated with internalised homonegativity in men who have sex with men: findings from the European MSM Internet Survey (EMIS) in 38 countries. Social Science E Medicine, 78, 61-69. https://dx.doi.org/10.1016/j.socscimed.2012.11.033.

Berg, R. C., Weatherburn, P., Ross, M. W., \& Schmidt, A .J. (2015). The relationship of internalized homonegativity to sexual health and well-being among men in 38 European countries who have sex with men. Journal of Gay E Lesbian Mental Health, 19(3), 285-302. https://dx.doi.org/10.1080/19359705.2015.1024375.

Berghe, W. V., Dewaele, A., Cox, N., \& Vincke, J. (2010). Minority-specific determinants of mental well-being among lesbian, gay, and bisexual youth. Journal of Applied Social Psychology, 40(1), 153-166. https://dx.doi.org/10.1111/j.1559-1816.2009.00567.x.

Bolshov, Ye. S., Kasianchuk, M. G., Leshchynskyi, Ye. B., Trofymenko, L. V., \& Shvab, I. A. (2012). Behavior monitoring and HIV-prevalence among men who have sex with men as a component of second generation surveillance (Analytical report). Retrieved from HIV/AIDS Alliance in Ukraine website: http://www.aidsalliance.org.ua/ru/library/our/.../msm_en_2011.pdf.

Byrne, B. M. (2012). Structural equation modeling with Mplus: basic concepts, applications, and programming. New York, NY: Routledge/Taylor \& Francis Group. 
Byrne, B. M., Shavelson, R. J., \& Muthen, B. (1989). Testing for the equivalence of factor covariance and mean structures: the issue of partial measurement invariance. Psychological Bulletin, 105(3), 456-466. https://dx.doi.org/10.1037/0033-2909.105.3.456.

Cronbach, L. J. (1951). Coefficient alpha and the internal structure of tests. Psychometrika, 16(3), 297-334.

Currie, M. R., Cunningham, R. G., \& Findlay, B. M. (2004). The Short Internalized Homonegativity Scale: examination of the factorial structure of a new measure of internalized homophobia. Educational and Psychological Measurement, 64(6), 1053-1067. https://dx.doi.org/10.1177/0013164404264845.

Dubov, A., Fraenkel, L., Yorick, R., Ogunbajo, A., \& Altice, F. L. (2018). Strategies to implement pre-exposure prophylaxis with men who have sex with men in Ukraine. AIDS and Behavior, 22(4), 1100-1112. https://dx.doi.org/10.1007/s10461-017-1996-y.

Hequembourg, A. L., \& Dearing, R. L. (2013). Exploring shame, guilt, and risky substance use among sexual minority men and women. Journal of Homosexuality, 60(4), 615-638. https://dx.doi.org/10.1080/00918369.2013.760365.

Herek, G. M. (2004). Beyond "homophobia": thinking about sexual prejudice and stigma in the twenty-first century. Sexuality Research E Social Policy, 1(2), 6-24.

Herek, G. M., Cogan, J. C., Gillis, J. R., \& Glunt, E. K. (1998). Correlates of internalized homophobia in a community sample of lesbians and gay men. Journal of the Gay E E Lesbian Medical Association, 2(1), 17-25.

Herek, G. M., Gillis, J. R., \& Cogan, J. C. (2009). Internalized stigma among sexual minority adults: insights from a social psychological perspective. Journal of Counseling Psychology, 56(1), 32-43. https://dx.doi.org/10.1037/a0014672.

Huebner, D. M., Davis, M. C., Nemeroff, C. J., \& Aiken, L. S. (2002). The impact of internalized homophobia on HIV preventive interventions. American Journal of Community Psychology, 30(3), 327-348. https://dx.doi.org/10.1023/A:1015325303002.

IBM Corp. Released. (2013). IBM SPSS Statistics for Windozes, Version 22.0. Armonk, NY: IBM Corp.

Johnson, M. O., Carrico, A. W., Chesney, M. A., \& Morin, S. F. (2008). Internalized heterosexism among HIV-positive, gay-identified men: implications for HIV prevention and care. Journal of Consulting and Clinical Psychology, 76(5), 829-839.

Kasianchuk, M., Trofymenko, O., Bilous, Ye., \& Sazonova, Ya. (2017). Monitoring behavior and HIV-prevalence among men having sex with men (National analytical report). [In Ukrainian]. Kyiv. Ukraine: Alliance for Public Health. [= Касянчук 2017]

Kasianczuk, M. (2014). The internal homophobia of bisexual men. [In Russian]. In A.A. Kondakov (Ed.), At a crossroads: methodology, theory and practice of LGBT and queer studies (pp. 391-409). Saint Petersburg, Russian Federation: Centre for Independent Social Research. [= Касянчук 2014]

Kharchenko, I. (2014). Adapting to adverse conditions: LGBT coming out strategies in Ukraine (Master's thesis, Central European University). Retrieved from www.etd.ceu.hu/2014/kharchenko_ievgeniia.pdf.

Lapshina, T. N., \& Kochetkova, A. S. (2016). The mental health of LGB teenagers and young adults as a challenge to Russian psychologists. [In Russian]. Psychology. Journal of the Higher School of Economics, 13(1), 40-59. [= Лапшина 2016]

Lingiardi, V., Baiocco, R., \& Nardelli, N. (2012). Measure of internalized sexual stigma for lesbians and gay men: a new scale. Journal of Homosexuality, 59(8), 1191-1210. https://dx.doi.org/10.1080/00918369.2012.712850.

Lohmus, L., Murd, M., \& Trummal, A. (2012). European MSM Internet Survey (EMIS): the results for Estonia (Analytical report). [In Estonian]. Tallinn, Estonia: Tervise Arengu Institu- 
ut (National Institute for Health Development). Retrieved from http://rahvatervis.ut.ee/bitstream/1/4960/1/TAI2012_3.pdf.

Lottes, I. L., \& Alkula, T. (2011). An investigation of sexuality-related attitudinal patterns and characteristics related to those patterns for 32 European countries. Sexuality Research and Social Policy, 8(2), 77-92. https://dx.doi.org/10.1007/s13178-011-0038-1.

Malyon, A. K. (1982). Psychotherapeutic implications of internalized homophobia in gay men.Journal of Homosexuality, 7(2-3), 59-69. https://dx.doi.org/10.1300/J082v07n02_08.

Mayfield, W. (2001). The development of an Internalized Homonegativity Inventory for gay men.Journal of Homosexuality, 41(2), 53-76. https://dx.doi.org/10.1300/J082v41n02_04.

Meyer, I., \& Dean, L. (1998). Internalized homophobia, intimacy, and sexual behavior among gay and bisexual men. In G. M. Herek (Ed.), Psychological perspectives on lesbian and gay issues, Vol. 4. Stigma and sexual orientation: understanding prejudice against lesbians, gay men, and bisexuals (pp. 160-186). https://dx.doi.org/10.4135/9781452243818.n8.

Morell-Mengual, V., Gil-Llario, M. D., Ballester-Arnal, R., \& Salmeron-Sanchez, P. (2017). Spanish adaptation and validation of the Short Internalized Homonegativity Scale (SIHS). Journal of Sex EF Marital Therapy, 43(4), 298-305.

https://dx.doi.org/10.1080/0092623X.2016.1149128.

Moskotina, R., Dmitruk, N., Trofimenko, O., Privalov, Yu., \& Kasianczuk, M. (2017). Study on the attitudes of staff of key social services of five countries of Central and Eastern Europe and Central Asia towards LGBT people, conducted within the framework of ECOM's regional program "Right to Health" (Analytical report). Tallinn, Estonia: Eurasian Coalition on Male Health.

Muthén, L. K., \& Muthén, B. O. (1998-2012). Mplus user's guide. Seventh edition. Los Angeles, CA: Muthén \& Muthén.

Newcomb, M. E., \& Mustanski, B. (2011). Moderators of the relationship between internalized homophobia and risky sexual behavior in men who have sex with men: a meta-analysis. Archives of Sexual Behavior, 40(1), 189-199. https://dx.doi.org/10.1007/s10508-009-9573-8.

Nungesser, L. G. (1983). Homosexual acts, actors, and identities. Santa Barbara, CA: Praeger.

Parker, R. D., Lohmus, L., Mangine, C., \& Ruutel, K. (2016). Homonegativity and associated factors among men who have sex with men in Estonia.Journal of Community Health, 41(4), 717-723. https://dx.doi.org/10.1007/s10900-015-0145-7.

Pew Research Center. (2017). Religious belief and national belonging in Central and Eastern Europe (Survey report). Retrieved from http://www.pewforum.org/2017/05/10/ religious-belief-and-national-belonging-in-central-and-eastern-europe.

Pyun, T., Santos, G. M., Arreola, S., Do, T., Hebert, P., Beck, J., ... Ayala, G. (2014). Internalized homophobia and reduced HIV testing among men who have sex with men in China. Asia Pacific Journal of Public Health, 26(2), 118-125.

https://dx.doi.org/10.1177/1010539514524434.

Ross, M. W., Berg, R. C., Schmidt, A. J., Hospers, H. J., Breveglieri, M., Furegato, M., \& Weatherburn, P. (2013). Internalised homonegativity predicts HIV-associated risk behavior in European men who have sex with men in a 38-country cross-sectional study: some public health implications of homophobia. BMJ Open, 3(2), e001928.

https://dx.doi.org/10.1136/bmjopen-2012-001928.

Ross, M. W., Kajubi, P., Mandel, J. S., McFarland, W., \& Raymond, H. F. (2013). Internalized homonegativity/homophobia is associated with HIV-risk behaviors among Ugandan gay and bisexual men. International Journal of STD E $\mathcal{F}$ AIDS, 24(5), 409-413. https://dx.doi.org/10.1177/0956462412472793. 
Ross, M., \& Simon Rosser, B. R. (1996). Measurement and correlates of internalized homophobia: a factor analytic study. Journal of Clinical Psychology, 52(1), 15-21. https://dx.doi.org/10.1002/(SICI)1097-4679(199601)52:1<15::AID-JCLP2>3.0.CO;2-V.

Ross, M. W., Simon Rosser, B. R., Neumaier, E. R., \& Positive Connections Team (2008). The relationship of internalized homonegativity to unsafe sexual behavior in HIV seropositive men who have sex with men. AIDS Education and Prevention, 20(6), 547-557. https://dx.doi.org/10.1521/aeap.2008.20.6.547.

Ross, M. W., Smolenski, D. J., Kajubi, P., Mandel, J .S., McFarland, W., Raymond, F. H. (2010). Measurement of internalized homonegativity in gay and bisexual men in Uganda: cross-cultural properties of the Internalized Homonegativity scale. Psychology, Health $\mathcal{E}^{\circ}$ Medicine, 15(2), 159-165.

Rosser, S. (2011, November). The relationship between discrimination, homophobia, mental health and HIV risk: findings from the SILAS study. Paper presented at FEMP Conference. Retrieved from https://www.folkhalsomyndigheten.se/contentassets/ce6e1b196d2541e6a3b 417a6b4bcb031/femp-2011-future-european-prevention-men-have-sex-with-men.pdf.

Rosser, B. R., Bockting, W. O., Ross, M. W., Miner, M. H., \& Coleman, E. (2008). The relationship between homosexuality, internalized homo-negativity, and mental health in men who have sex with men. Journal of Homosexuality, 55(2), 185-203.

https://dx.doi.org/10.1080/00918360802129394.

Sabunaieva, M. L. (2011). Internalized homophobia: Do I fear myself? [In Russian]. Saint Petersburg, Russian Federation. [= Сабунаева 2011]

Santos, G. M., Beck, J., Wilson, P. A., Hebert, P., Makofane K., Pyun, T., ... Ayala, G. (2013). Homophobia as a barrier to HIV prevention service access for young men who have sex with men.JAIDS: Journal of Acquired Immune Deficiency Syndrome, 63(5), e167-e170.

Shestakovskii, O., \& Kasianczuk, M. (2018). A study on internalized homonegativity (Analytical report). [In Russian]. Tallinn, Estonia: Eurasian Coalition on Male Health. Retrieved from https://ecom.ngo/wp-content/uploads/2018/09/Issledovanie-internalizirovannojgomonegativnosti-_RU.pdf. [= Шестаковский 2018]

Shestakovskyi, O., Kasianchuk, M., Garner, A., Howell, S., Djuma, V., \& Sabelashvili, P. Internalized homonegativity decreases access to condoms among MSM in 10 countries of Eastern Europe and Central Asia. (2018, July). Paper presented at AIDS 2018 Conference. Retrieved from https://programme.aids2018.org//PAGMaterial/eposters/5139.pdf.

Shidlo, A. (1994). Internalized homophobia: Conceptual and empirical issues in measurement. In B. Greene \& G. M. Herek (Eds.), Psychological perspectives on lesbian and gay issues, Vol. 1. Lesbian and gay psychology: theory, research, and clinical applications (pp. 176-205). Thousand Oaks, CA: Sage. https://dx.doi.org/10.4135/9781483326757.n10.

Shmykova, Ye. (2011). European MSM Internet Survey (EMIS): the results for Russia (Analytical report). [In Russian]. Retrieved from http://www.emis-project.eu/sites/default/ files/public/publications/EMIS_NationalReport_Russia.pdf. [= Шмыкова 2011]

Shoptaw, S., Weiss, R. E., Munjas, B., Hucks-Ortiz, C., Young, S. D., Larkins, S., ... Gorbach, P. M. (2009). Homonegativity, substance use, sexual risk behaviors, and HIV status in poor and ethnic men who have sex with men in Los Angeles. Journal of Urban Health, 86(Suppl 1), 77-92. https://dx.doi.org/10.1007/s11524-009-9372-5.

Smolenski, D. J., Diamond, P. M., Ross, M. W., \& Simon Rosser, B. R. (2010). Revision, criterion validity, and multi-group assessment of the Reactions to Homosexuality Scale. Journal of Personality Assessment, 92(6), 568-576. https://dx.doi.org/10.1080/00223891.2010.513300.

Smolenski, D. J., Ross, M. W., \& Simon Rosser, B. R. (2011). Direct and indirect effects between internalized homonegativity and high-risk sex. Archives of Sexual Behavior, 40(4), 785-792. https://dx.doi.org/10.1007/s10508-010-9705-1. 
Szymanski, D. M., Kashubeck-West, S., \& Meyer, J. (2008). Internalized heterosexism: a historical and theoretical overview. The Counseling Psychologist, 36(4), 510-524. https://dx.doi.org/10.1177/0011000007309488.

The EMIS Network. (2013). EMIS 2010: the European Men-Who-Have-Sex-With-Men Internet Survey. Findings from 38 countries (Technical report). Stockholm: European Centre for Disease Prevention and Control. Retrieved from https://ecdc.europa.eu/sites/portal/files/media/ en/publications/Publications/EMIS-2010-european-men-who-have-sex-with-men-survey.pdf.

Tran, H., Ross, M. W., Diamond, P. M., Berg, R. C., Weatherburn, P., \& Schmidt, A. J. (2018). Structural validation and multiple group assessment of the Short Internalized Homonegativity Scale in homosexual and bisexual men in 38 European countries: results from the European MSM Internet Survey. The Journal of Sex Research, 55(4-5), 617-629. https://dx.doi.org/10.1080/00224499.2017.1380158.

Vu, L., Tun, W., Sheehy, M., \& Nel, D. (2012). Levels and correlates of internalized homophobia among men who have sex with men in Pretoria, South Africa. AIDS and Behavior, 16(3), 717-723. https://dx.doi.org/10.1007/s10461-011-9948-4.

Wang, J., \& Wang, X. (2012). Structural equation modeling: applications using Mplus. Hoboken, NJ: John Wiley \& Sons.

Weatherburn, P., Schmidt, A. J., Hickson, F., Reid, D., Berg, R. C., Hospers, H. J., ... EMIS Network. (2013). The European Men-Who-Have-Sex-with-Men Internet Survey (EMIS): design and methods. Sexuality Research and Social Policy, 10(4), 243-257.

https://dx.doi.org/10.1007/s13178-013-0119-4. Press.

Weinberg, G. H. (1972). Society and the healthy homosexual. New York, NY: St Martin's

Wilkerson, J. M., Smolenski, D. J., Brady, S. S., \& Simon Rosser, B. R. (2012). Religiosity, internalized homonegativity, and outness in Christian men who have sex with men. Sexual and Relationship Therapy, 27(2), 122-132. https://dx.doi.org/10.1080/14681994.2012.698259.

Williamson, I. R. (2000). Internalized homophobia and health issues affecting lesbians and gay men. Health Education Research, 15(1), 97-107.

https://dx.doi.org/10.1093/her/15.1.97.

Xu, W., Zheng, L., Xu, Y., \& Zheng, Y. (2017). Internalized homophobia, mental health, sexual behaviors, and outness of gay/bisexual men from Southwest China. International Journal for Equity in Health, 16:36. https://dx.doi.org/ 10.1186/s12939-017-0530-1.

Yanykin, A. A., \& Nasledov, A. D. (2017). Internalized homophobia in Russia. Psychology in Russia: State of the Art, 10(2), 103-116. https://dx.doi.org/10.11621/pir.2017.0207.

Young, S. D., Shoptaw, S., Weiss, R. E., Munjas, B., \& Gorbach, P. M. (2011). Predictors of unrecognized HIV infection among poor and ethnic men who have sex with men in Los Angeles. AIDS and Behavior, 15(3), 643-649. https://dx.doi.org/10.1007/s10461-009-9653-8.

Received 26.02.2019

\section{OLEKSII SHESTAKOVSKYI, MAXIM KASIANCZUK, OLESIA TROFYMENKO, GULBARSHYN CHEPURKO, VITALY DJUMA, SEAN HOWELL}

\section{Internal homonegativity among men having sex with men: a comparative cross-national study}

The paper studies internalized homonegativity (IH) and its predictors among men who have sex with men (MSM) in 12 countries of Eastern Europe and Central Asia (EECA). Internalized homonegativity (sometimes called internal homophobia) is a negative attitude to own same-sex 
attractions. It arises when gays and other people with homosexual attractions interiorize predominant negative attitudes and assumptions about homosexuals and homosexuality.

Internalized homonegativity is a significant factor of poorer health (including vulnerability to HIV infection), and lower inclusion in the community in Western countries. It remains highly understudied in post-Soviet countries, although there is a sufficient ground to suppose its higher prevalence here.

Cross-sectional online survey of MSM was conducted in August-October, 2017. Convenience sample was recruited via dating apps and websites, other partner sites, and MSM-service organizations. Analytical sample size was 8239 respondents from Russia, Ukraine, Belarus, Kazakhstan, Kyrgyzstan, Estonia and Lithuania (which were merged), Armenia, Georgia, Azerbaijan, Macedonia, and Moldova.

IH was measured by the 8-item Short Internalized Homonegativity Scale (SIHS) in all main languages of the countries. According to results of Cronbach's a test and multi-group confirmatory factor analysis, adaptation of SIHS showed satisfactory to good reliability, and partial scalar invariance across EECA.

IH was not predominant in all countries' samples. However, average IH was significantly different by countries. That could be attributed to both sampling design and differences in societal homophobia. Results of structural equation modeling of SIHS predictors also varied between countries. However, in most countries IH was lower among self-identified gays, those who were more open about own homosexual attractions, and was less religious. The unexpected findings included negative associations between IH and higher education, and contradictory associations with age in some countries.

Results showed that internalized homonegativity is a common and comparable phenomenon among MSM in Eastern Europe and Central Asia. Its prevalence is presumably different across the countries. IH relates, first of all, to own sexual orientation (gay, bi- etc.), and acknowledgement of own same-sex attractions. Also, the SIHS measure is good enough for use in further studies of male health and possibilities for LGBTIQ mobilization in the region.

Keywords: internalized homonegativity, homosexuality, MSM, EECA, homophobia, measurement invariance, structural equation modeling

\section{ОЛЕКСІЙ ШЕСТАКОВСЬКИЙ, МАКСИМ КАСЯНЧУК, ОЛЕСЯ ТРОФИМЕНКО, ГУЛЬБАРШИН ЧЕПУРКО, ВІТАЛІЙ ДЖУМА, ШОН ГАУВЕЛ}

\section{Внутрішня гомонеґативність серед гомо- та бісексуальних чоловіків: порівняльне дослідження}

Досліджено інтерналізовану гомонегативність (IГ) та ї чинники серед чоловіків, які практикують секс з чоловіками (ЧСЧ) у 12 країнах Східної Свропи та Центральної Азії (СЕЦА). Інтерналізована гомонегативність (яку інколи називають внутрішньою гомофобією) є негативним ставленням до власних одностатевих потягів. Вона виникає тоді, колигеїта інші людизгомосексуальними потягами засвоюють панівні нетативнінастанови й переконання про гомосексуалів і гомосексуальність.

Інтерналізована гомонегативність є важливим чинником гіршого стану здоров'я (включно з уразливістю до ВІЛ-інфекиії) й меншої включеності в життя спільноти в західних країнах. У пострадянських крайнах ї̈ феномен майже не вивчено, хоча є достатньо підстав вважати IГ більш поширеною тут.

Крос-секиійне онлайн-опитування ЧСЧбуло проведено в серпні-жовтні 2017 року. Вибірка була зручною за дизайном (сопуепіепсе sample). Рекрутинг здійснено на підставі додатків та веб-сайтів для знайомств, інших партнерських сайтів та ЧСЧ-сервісних організачій. Обсяг аналітичної вибірки становив 8239 респондентів з Росії, України, Біло- 
русі, Казахстану, Киргизї, Естонії та Литви (які ми об’єднали), Вірменії, Грузї, Азербайджану, Македонії та Молдови.

Ми вимірювали IГ за допомоги Короткої икали інтерналізованої гомонегативності (КШІГ), що містить вісім суджень на основних мовах досліджуваних країн. Відповідно до $\alpha$ Кронбаха та багатогрупового конфірматорного факторного аналізу, наша адаптація КШІГ показала задовільний або хороший рівень надійності та часткову або повну скаляр ну інваріантність у країнах СЕЦА.

Більшість опитаних в усіх країнах не мали вираженої IГ. Проте середній рівень IГ значущо відрізнявся поміж країнами. Це можна пояснити як дизайном вибірки, так ірізними рівнями сочієтальної гомофобії. Результати моделювання структурними рівняннями чинників КШІГ також відрізнялися поміж крайнами. Однак у більшості країн IГ був нижчим серед чоловіків, які визначали себе як геїв, більш відкритих щодо власних одностатевих потягів $і$ мени релігійних. Неочікуваними висновками виявилися негативні зв'язки між ІГ і вищою освітою, а також суперечливі зв'язки з віком у деяких країнах.

Таким чином, інтерналізована гомонегативність є спільним і порівнюваним феноменом серед ЧСЧ Східної Європи та Центральної Азії. Ї̈ поширеність відрізняється поміж країнами і пов'язана передусім із власною сексуальною орієнтацією (гей, бісексуал тощо) та з визнанням власних одностатевих потягів. Крім того, шкала КШІГ є придатною для подальшого вивчення здоров'я чоловіків та можливостей мобілізачї ЛГБТІК в регіоні.

Ключові слова: інтерналізована гомонегативність, гомосексуальність, ЧСЧ, СЕЦА, гомофобія, інваріантність вимірювання, моделювання структурними рівняннями

\section{АЛЕКСЕЙ ШЕСТАКОВСКИЙ, МАКСИМ КАСЯНЧУК, ОЛЕСЯ ТРОФИМЕНКО, ГУЛЬБАРШИН ЧЕПУРКО, ВИТАЛИЙ ДЖУМА, ШОН ГАУВЕЛ}

\section{Внутренняя гомонегативность среди гомо- и бисексуальных мужчин: сравнительное исследование}

Исследована интернализированная гомонегативность (ИГ) и ее факторы среди мужчин, практикуюших секс с мужчинами (МСМ) в 12 странах Восточной Европы и Центральной Азии (ВЕЦА). Интернализированная гомонегативность (которую иногда называют внутренней гомофобией) является негативным отношением к собственным однополым влечениям. Она возникает тогда, когда геи и другие люди с гомосексуальными влечениями усваивают господствующие негативные установки и убеждения о гомосексуалах и гомосексуальности.

Интернализированная гомонегативность является важным фактором плохого состояния здоровья (включая уязвимость для ВИЧ-инфекции) и меньшей включенности в жизн сообщества в западных странах. В постсоветских странах ее феномен почти не изучен, хотя имеется достаточно оснований считать ИГ здесь более распространенной.

Кросс-секционный онлайн-опрос МСМ проводился в августе-октябре 2017 года. Выборка была удобной по дизайну (сопvепіепсе sample). Рекрутинг осуществлен на основе приложений и веб-сайтов для знакомств, других партнерских сайтов и МСМ-сервисньх организаиий. Объем аналитической выборки составлял 8239 респондентов из России, Украины, Беларуси, Казахстана, Киргизии, Эстонии и Литвы (которые мы объединили), Армении, Грузии, Азербайджана, Македонии и Молдовы.

Мы измеряли ИГ при помощи Короткой шкалы интернализированной гомоненативности (КШИГ), содержащей восемь суждений на основных языках исследуемьх стран. Согласно Кронбаха и многогрупповому конфирматорному факторному анализу, наша адаптаиия КШИГ показала удовлетворительный или хороший уровень надежности и частичную или полную скалярную инвариантность в странах ВЕЦА. 
Internal homonegativity among men having sex with men: a comparative cross-national study

Большинство опрошенных во всех странах не имели выраженной ИГ. Однако средний уровень ИГ значимо разнился между странами. Это можно объяснить как дизайном выборки, так и разными уровнями сочиетальной гомофобии. Результаты моделирования структурными уравнениями факторов КШИГ также различались между странами. Однако в большинстве стран ИГ был ниже среди мужчин, которые определяли себя как геев, более открытых в плане собственных однополых влечений и менее религиозных. Неожиданными выводами оказались негативныесвязи между ИГи высиим образованием, а также противоречивые связи с возрастом в некоторых странах.

Таким образом, интернализированная гомоненативность является общим и сравниваемым феноменом среди МЧМ Восточной Европь и Центральной Азии. Ее распространенность различна между странами и связана преждевсего с собственной сексуальной ориентаиией (гей, бисексуал и т.п.) и с признанием собственных однопольх влечений. Кроме того, шкала КШИГ пригодна для дальнейшего изучения здоровья мужчин и возможностей мобилизачии ЛГБТИК в регионе.

Ключевые слова: интернализированная гомонегативность, гомосексуальность, МСМ, ВЕЦА, гомофобия, инвариантность измерения, моделирование структурными уравнениями 